\title{
PENGARUH KOMITE AUDIT (AUDIT MEETING), MANAGERIAL DIRECTOR TERHADAP KONSERVATISME AKUNTANSI (Studi pada Industri Ritel yang Terdaftar di Bursa Efek Indonesia Tahun 2012-2016) OWNERSHIP, FOREIGN OWNERSHIP, DAN INDEPENDENT
}

\author{
Fitri Anjani ${ }^{1}$, Dudi Pratomo, S.E.T., M.Ak ${ }^{2}$, Kurnia, S.AB., M.M ${ }^{3}$ \\ ${ }^{1,2,3}$ Prodi S1 Akuntansi, Fakultas Ekonomi dan Bisnis, Universitas Telkom \\ 19anjani.fa@gmail.com, ${ }^{2}$ dudipratomo@telkomuniversity.ac.id, \\ 3akukurnia@telkomuniversity.ac.id
}

\begin{abstract}
Conservatism is prudence principle in the preparation of financial reporting in which the company is not rush to recognizing revenue and profit as well as immediatilly recognize cost and loss that have possibility of occurring. The prudence principle is referred to accounting conservatism.

This study aimed to obtain empirical evidence of the influence of the audit committee, managerial ownership, foreign ownership, and independent director to accounting conservatism. The population in this study is a sub company retail industry sector listed on the Indonesia Stock Exchange in 2012-2016.

Mechanical sample selection using purposive sampling and acquired 5 companies by 5 years in order to get 25 samples was observed. Model analysis of the data in this research is panel data regression using Software Eviews 9.0.

This study shows that independent variables such as the audit committee, managerial ownership, foreign ownership, and independent director simultaneously affect the dependent variable accounting conservatism. In partial of variable audit committee significant positive effect on accounting conservatism, variabel independent director significant negative effect on accounting conservatism. Meanwhile, the variable managerial ownership and foreign ownership no significant effect on accounting conservatism.

Conclusions of this research is the audit committee and independent director significant effect on accounting conservatism, while managerial ownership and foreign ownership has no effect and can reduce the accounting conservatism at the company. Suggestions for the company is to increase the amount of managerial share ownership and for the investor to see the company that have a high proportion of foreign share ownership. As for further research, can use other measurement methods to measure conservatism as using Zhang or Basu method.
\end{abstract}

From the test results obtained partial results showing variable levels of financial difficulty with negative direction have a significant effect on accounting conservatism. Variable litigation risk and growth opportunities no significant effect on accounting conservatism.

Keywords: Audit Committee, Managerial Ownership, Foreign Ownership, Independent Director, and Accounting Conservatism. 


\section{Pendahuluan}

Laporan keuangan merupakan salah satu bentuk pertanggungjawaban perusahaan kepada pihak-pihak yang memiliki kepentingan. Menurut Oktomegah (2012) laporan keuangan dijadikan salah satu indikator dalam pengambilan keputusan, oleh karena itu manajemen akan sebaik mungkin menyajikan laporan keuangan perusahaannya. Kebebasan manajemen dalam memilih metode akuntansi dapat dimanfaatkan untuk menghasilkan laporan keuangan yang berbeda-beda disetiap perusahaan sesuai dengan keinginan dan kebutuhan perusahaan.

PT. Inovisi Infracom Tbk (INVS) mendapat sanksi penghentian sementara (suspen) perdagangan saham oleh PT Bursa Efek Indonesia (BEI). Sanksi ini diberikan karena ditemukan banyak kesalahan dilaporan kinerja keuangan perusahaan kuartal III-2014 (https://finance.detik.com). Sedangkan, perkembangan industri ritel di Indonesia saat ini sedang melemah. Bahkan beberapa perusahaan ritel memutuskan menutup toko mereka di Indonesia pada tahun 2017. Melemahnya daya beli masyarakat memberikan tekanan pada perusahaan ritel. Hal ini diperkuat dengan informasi bahwa PT. Sumber Alfaria Trijaya Tbk (AMRT) tengah menghadapi beban utang yang meningkat. Hal tersebut membuat manajemen harus memutar otak agar tetap bertahan. Manajemen mengakui kenaikan beban bunga tersebut akan mempengaruhi kegiatan operasional sehingga berdampak pada pertumbuhan laba (https://finance.detik.com).

Keputusan investor untuk menanamkan sejumlah modalnya tersebut tak lepas dari analisa terhadap laporan keuangan perusahaan yang sehat. Pemberi pinjaman dan Investor biasanya memilih Debt to Equity Ratio yang rendah karena kepentingan mereka lebih terlindungi jika terjadi penurunan bisnis pada perusahaan yang sehat. Oleh karena itu, dibutuhkan tindakan kehati-hatian dalam menyajikan laporan keuangan untuk menjaga reputasi perusahaan dan faktor-faktor lain yang menyebabkan suatu kondisi yang buruk. Kehati-hatian tersebut meliputi pengakuan aktiva, pendapatan, kewajiban dan beban. Tindakan kehati-hatian pengakuan tersebut dalam menyajikan laporan keuangan disebut konservatisme akuntansi.

Suwardjono (2010:245) mendefinisikan konservatisme adalah sikap atau aliran (mazhab) dalam menghadapi ketidakpastian untuk mengambil suatu tindakan atau keputusan atas dasar munculan (outcome) yang terjelek dari ketidakpastian tersebut. Sikap konservatif juga mengandung makna sikap berhati-hati dalam menghadapi risiko dengan cara bersedia mengorbankan sesuatu untuk mengurangi atau menghilangkan risiko. Prinsip konservatisme mengakui biaya dan rugi lebih cepat, pendapatan dan untung lebih lambat, menilai aktiva dengan nilai yang terendah, dan kewajiban dengan nilai yang tertinggi. Dengan penerapan prinsip tersebut, perusahaan akan lebih mengantisipasi tidak ada keuntungan dan lebih cepat mengakui terjadinya kerugian atau biaya.

Dalam penelitian ini variable yang akan diteliti adalah komite audit (audit meeting), managerial ownership, foreign ownership, dan independent director untuk mengetahui pengaruhnya terhadap konservatisme akuntansi. 


\section{Tinjauan Pustaka Penelitian}

2.1 Konservatisme Akuntansi

Konservatisma adalah sikap atau aliran (mazhab) dalam menghadapi ketidakpastian untuk mengambil tindakan atau keputusan atas dasar muncul (outcome) yang terjelek dari ketidakpastian tersebut. Sikap konservatif juga mengandung makna sikap berhati-hati dalam menghadapi risiko dengan cara bersedia mengorbankan sesuatu untuk mengurangi atau menghilangkan risiko (Suwardjono, 2010:245).

Menurut Givoly dan Hayn (2002) dalam Savitri (2016:53) ukuran konservatisme diukur dengan menggunakan ukuran akrual. Rumus untuk mengukur konservatisme yaitu:

Dimana:

$$
\text { Cit }=\text { Nlit }- \text { CFOit }
$$

Cit $=$ Nilai akrual pada perusahaan $i$ dalam waktu $t$

Niit = Laba Sebelum Extraordinary Items dikurangi depresiasi dan amortisasi CFOit $=$ Cash flow dari kegiatan operasional

Proksi konservatisme yang dikembangkan oleh Givoly dan Hayn (2002) yaitu besaran akrual, apabila akrual bernilai negatif maka laba digolongkan konservatif, dan sebaliknya.

\subsection{Komite Audit}

Komite Audit adalah komite yang berfungsi membantu dewan komisaris dalam memastikan dilaksanakannya tata kelola perusahaan yang baik, yang meliputi tugas-tugas untuk mengkaji perencanaan audit baik oleh pihak internal maupun eksternal, menelaah laporan audit internal dan eksternal, menelaah penerapan tata kelola perusahaan, etika bisnis serta pedoman perilaku (Savitri, 2016:69).

Pada penelitian ini, komite audit diproksikan dengan audit meeting. Menurut Peraturan OJK Nomor. 55/POJK.04/2015 tentang Pembentukan dan Pedoman Pelaksanaan Kerja Komite Audit, menyebutkan bahwa komite audit mengadakan rapat secara berkala paling sedikit 1 (satu) kali dalam 3 (tiga) bulan. Rapat Komite Audit dapat diselenggarakan apabila dihadiri oleh lebih dari $1 / 2$ (satu per dua) jumlah anggota dan keputusan rapat Komite Audit diambil berdasarkan musyawarah mufakat. Dalam penelitian ini, komite audit diukur dengan melihat banyaknya jumlah rapat yang dilakukan komite audit dalam satu tahun.

\section{Audit Meeting $=$ jumlah frekuensi rapat dalam satu tahun}

\subsection{Managerial Ownership}

Menurut Imanta dan Satwiko (2011), kepemilikan manajerial adalah kepemilikan saham perusahaan oleh pihak manajer, atau dengan kata lain manajer juga sekaligus sebagai pemegang saham. Dengan adanya kepemilikan manajerial, tentu akan mendorong pihak manajer untuk bertindak sejalan dengan keinginan pemegang saham dengan meningkatkan kinerja dan tanggung jawab dalam mencapai kemakmuran pemegang saham. Hal ini dikarenakan manajer akan merasakan langsung manfaat dari setiap keputusan yang diambil dan juga kerugian yang timbul apabila membuat keputusan yang salah. Kepemilikan saham diukur dengan membandingkan antara jumlah saham yang dimiliki pihak 
manajemen dengan seluruh modal saham perusahaan yang beredar. Rumus untuk menghitung persentase kepemilikan manajerial adalah sebagai berikut:

$$
\text { Kepemilikan Manajerial }=\frac{\sum \text { saham yang dimiliki pihak manajemen }}{\sum \text { saham yang beredar }} \times 100 \%
$$

\subsection{Foreign Ownership}

Kepemilikan asing merupakan proporsi saham biasa yang dimiliki perusahaan secara perorangan, badan hukum, pemerintah serta bagianbagiannya yang berstatus luar negeri atau bukan berasal dari Indonesia. Kepemilikan asing mampu mengendalikan kebijakan manajemen karena memiliki kemampuan yang baik, sehingga berdampak pada penerapan konservatisme akuntansi (Kuspratiwi dan Widagdo, 2014). Kepemilikan asing dapat diukur sesuai dengan proporsi saham biasa yang dimiliki oleh asing. Rumus untuk menghitung persentase kepemilikan asing adalah sebagai berikut:

$$
\text { Kepemilikan Asing }=\frac{\sum \text { saham yang dimiliki pihak asing }}{\sum \text { saham beredar }} \times 100 \%
$$

\subsection{Independent Director}

Berdasarkan Surat Keputusan Direksi Bursa Efek Indonesia Nomor Kep0001/BEI/01-2014 Perihal Perubahan Peraturan No I-A Tentang Pencatatan Saham dan Efek Bersifat Ekuitas Selain Saham Yang Diterbitkan Oleh Perusahaan Tercatat, Direktur Independen merupakan direktur yang tidak memiliki hubungan afiliasi dengan pemegang saham pengendali Emiten yang bersangkutan sekurang-kurangnya selama 6 (bulan) sebelum penunjukan sebagai Direktur tidak terafiliasi, tidak memiliki hubungan afiliasi dengan Komisaris atau Direksi lainnya dari Emiten, tidak bekerja rangkap sebagai Direksi pada perusahaan lain, tidak merupakan orang dalam dari lembaga atau profesi penunjang pasar modal yang jasanya digunakan oleh Emiten selama 6 (bulan) sebelum penunjukan sebagai Direktur. Direktur independen dapat diukur dengan membandingkan jumlah proporsi direktur independen dengan jumlah direksi yang ada di perusahaan. Rumus untuk mengukur proporsi direktur independen adalah sebagai berikut:

$$
\text { Independent Director }=\frac{\sum \text { independent director }}{\sum \text { board of directors }} \times 100 \%
$$

\subsection{Kerangka Pemikiran}

\subsubsection{Komite Audit terhadap Konservatisme Akuntansi}

Sarra (2017) berpendapat bahwa komite audit bertugas melakukan kontrol dan pengawasan proses penyusunan laporan keuangan perusahaan untuk mengindari kecurangan yang dilakukan pihak manajemen. Komite audit terkait dengan frekuensi pertemuan komite audit, maka efektivitas komite audit dalam melaksanakan peran pengawasan atas proses pelaporan keuangan dan pengendalian internal memerlukan pertemuan rutin sebagai evaluasi dan pengawasan terhadap 
pihak manajemen yang mana hal ini akan membantu meningkatkan kualitas laporan keuangan perusahaan sangat diperlukan. Oleh karena itu, frekuensi pertemuan komite audit akan mempunyai pengaruh yang signifikan dalam penerapan konservatisme akuntansi yang digunakan oleh perusahaan (Bara, 2016). Penelitian yang dilakukan Wulandari dan Zulaikha (2012) menunjukkan bahwa frekuensi pertemuan komite audit berpengaruh signifikan positif terhadap tingkat konservatisme akuntansi.

\subsubsection{Managerial Ownership terhadap Konservatisme Akuntansi}

Menurut Imanta dan Satwiko (2011), kepemilikan manajerial adalah kepemilikan saham perusahaan oleh pihak manajer, atau dengan kata lain manajer juga sekaligus sebagai pemegang saham. Jika kepemilikan manajerial lebih banyak dibanding investor lain, maka manajemen cenderung melaporkan laba lebih konservatif. Karena rasa memiliki manajer terhadap perusahaan cukup besar, maka manajer berkeinginan untuk mengembangkan dan memperbesar perusahaan daripada mementingkan bonus yang didapat jika memenuhi target laba (Savitri, 2016:71). Penelitian yang dilakukan Pambudi (2017) menunjukkan bahwa pengaruh struktur kepemilikan manajerial signifikan positif terhadap konservatisme akuntansi.

\subsubsection{Foreign Ownership terhadap Konservatisme Akuntansi}

Kepemilikan asing merupakan proporsi saham biasa yang dimiliki perusahaan secara perorangan, badan hukum, pemerintah serta bagianbagiannya yang berstatus luar negeri atau bukan berasal dari Indonesia. Kepemilikan asing mampu mengendalikan kebijakan manajemen karena memiliki kemampuan yang baik, sehingga berdampak pada penerapan konservatisme akuntansi (Kuspratiwi dan Widagdo, 2014). Hal ini didukung oleh penelitian yang dilakukan oleh Kuspratiwi dan Widagdo (2014) menujukkan hasil bahwa kepemilikan asing berpengaruh secara signifikan positif terhadap konservatisme akuntansi.

\subsubsection{Independent Director terhadap Konservatisme Akuntansi}

Pengambilan keputusan dan kebijakan merupakan tugas dari Direktur. Pengambilan keputusan tergantung dari pendapat terbanyak dari Direksi yang ada. Pengambilan keputusan yang tidak tepat akan mempengaruhi kebijakan perusahaan tentunya menyangkut dengan pelaporan keuangan perusahaan terkait dengan prinsip akuntansi yang diterapkan pada perusahaan tersebut. Oleh karena itu, bila proporsi direktur independen memilih mengambil kebijakan untuk menerapkan prinsip konservatisme akuntansi, maka direktur independen berpengaruh positif terhadap konservatisme akuntansi. 


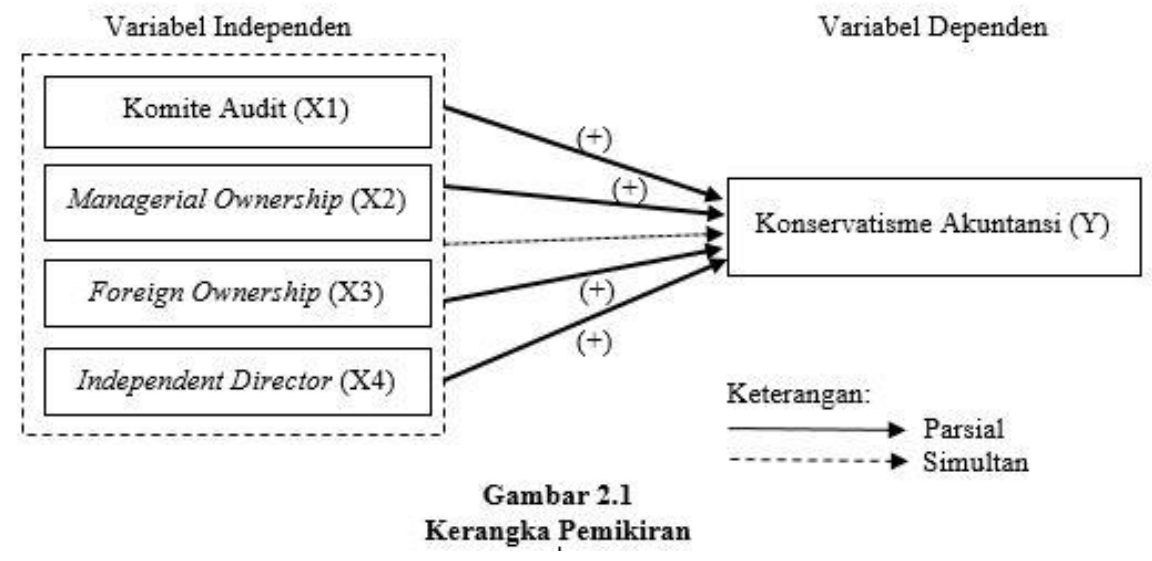

\subsection{Hipotesis Penelitian}

Berdasarkan teori dan kerangka pemikiran yang telah dipaparkan, maka dapat dirumuskan hipotesis penelitian sebagai berikut:

1. Komite Audit berpengaruh signifikan positif terhadap Konservatisme Akuntansi pada perusahaan industri ritel yang terdaftar di Bursa Efek Indonesia tahun 2012-2016.

2. Kepemilikan Manajerial (Managerial Ownership) berpengaruh signifikan positif terhadap Konservatisme Akuntansi pada perusahaan industri ritel yang terdaftar di Bursa Efek Indonesia tahun 2012-2016.

3. Kepemilikan Asing (Foreign Ownership) berpengaruh signifikan positif terhadap Konservatisme Akuntansi pada perusahaan industri ritel yang terdaftar di Bursa Efek Indonesia tahun 2012-2016.

4. Direktur Independen (Independent Director) berpengaruh signifikan positif terhadap Konservatisme Akuntansi pada perusahaan industri ritel yang terdaftar di Bursa Efek Indonesia tahun 2012-2016.

\section{Metode Penelitian}

\subsection{Populasi}

Menurut Sugiyono (2011:119) populasi adalah wilayah generalisasi yang terdiri atas: obyek atau subyek yang mempunyai kualitas dan karakteristik tertentu yang ditetapkan oleh peneliti untuk dipelajari dan kemudian ditarik kesimpulannya. Populasi yang digunakan sebagai bahan penelitian ini adalah perusahaan industri ritel yang terdaftar di Bursa Efek Indonesia tahun 20122016.

\subsection{Sampel}

Menurut Sekaran (2011:123) sampel adalah sebagian dari populasi. Sampel terdiri atas sejumlah anggota yang dipilih dari populasi. Metode pengambilan sampel pada penelitian ini adalah nonprobability sampling. Nonprobability sampling adalah teknik pengambilan sampel yang tidak memberi peluang atau kesempatan sama bagi setiap unsur atau anggota populasi untuk dipilih menjadi sampel (Sugiyono, 2011:125). Purposive sampling merupakan penarikan sampel yang dilakukan dengan memilih subjek berdasarkan kriteria 
spesifik yang ditetapkan peneliti. Purposive sampling adalah teknik penentuan sampel dengan pertimbangan tertentu (Sugiyono, 2011:126). Menurut Sugiyono (2009:124) jumlah anggota sampel yang paling tepat digunakan dalam penelitian yaitu tergantung pada tingkat ketelitian atau kesalahan yang dikehendaki. Tidak menyebutkan jumlah nominal berapa jumlah sampel yang tepat dalam penelitian tetapi dinyatakan dalam persentase. Menurut Gay dalam Umar (2013:79) menyatakan bahwa ukuran minimum sampel yang dapat diterima berdasarkan desain penelitian untuk metode deskriptif yaitu minimal $10 \%$ dari populasi. Berikut adalah kriteria-kriteria yang telah ditentukan dalam pemilihan sampel:

Tabel 1 Kriteria Pengambilan Sampel

\begin{tabular}{|c|l|c|}
\hline No & \multicolumn{1}{|c|}{ Kriteria } & Jumlah \\
\hline 1 & $\begin{array}{l}\text { Perusahaan industri ritel yang terdaftar di Bursa Efek } \\
\text { Indonesia tahun 2012-2016. }\end{array}$ & 19 \\
\hline 2 & $\begin{array}{l}\text { Perusahaan industri ritel yang terdaftar di Bursa Efek } \\
\text { Indonesia tahun 2012-2016 yang tidak konsisten } \\
\text { mempublikasikan laporan tahunan dan laporan } \\
\text { keuangan. }\end{array}$ & $(11)$ \\
\hline 3. & $\begin{array}{l}\text { Perusahaan industri ritel yang terdaftar di Bursa Efek } \\
\text { Indonesia tahun 2012-2016 yang tidak memiliki data } \\
\text { lengkap yang dibutuhkan selama periode penelitian. }\end{array}$ & 5 \\
\hline \multicolumn{2}{|c|}{ Jumlah Perusahaan yang memenuhi kriteria penelitian } \\
\hline \multicolumn{2}{|c|}{ Jumlah penelitian = 5 x 5 tahun } \\
\hline
\end{tabular}

Sumber: Data telah diolah penulis (2017)

Total sampel yang digunakan dalam penelitian ini adalah 25 sampel yang terdiri dari 5 perusahaan indutsri ritel dengan periode penelitian selama 5 tahun. Lima sampel perusahaan industri ritel yang digunakan dalam penelitian ini adalah:

1. Catur Sentosa Adiprana Tbk

2. Hero Supermarket Tbk

3. Matahari Departement Store Tbk

4. Mitra Adiperkasa Tbk

5. Ramayana Lestari Sentosa Tbk

\subsection{Analisis Regresi Data Panel}

Menurut Widarjono (2013:353) regresi menggunakan data panel disebut model regresi data panel. Ada beberapa keuntungan yang diperoleh dengan menggunakan data panel. Pertama, data panel yang merupakan gabungan dua data time series dan cross section mampu menyediakan data yang lebih banyak sehingga akan menghasilkan degree of freedom yang lebih besar. Kedua, menggabungkan informasi dari data time series dan cross section dapat 
ISSN

mengatasi masalah yang timbul ketika ada masalah penghilangan variabel (ommited-variabe). Persamaan analisis regresi model data panel menurut Basuki dan Prawoto (2016:276) adalah sebagai berikut:

Keterangan:

$$
\mathrm{Y}=\alpha+\beta_{1} \mathrm{X}_{1}+\beta_{2} \mathrm{X}_{2}+\beta_{3} \mathrm{X}_{3}+\beta_{4} \mathrm{X}_{4}+\mathrm{e}
$$
Y $\quad$ : konservatisme akuntansi
$\mathrm{X}_{3 \mathrm{it}} \quad:$ Foreign Ownerhsip
$\alpha \quad$ : Konstanta
$\mathrm{X}_{4 i t} \quad$ : Independent Director

$\beta_{1} \beta_{2} \beta_{3} \beta_{4}$ : Koefisien regresi masing-masing vaiabel independen

e : Error term

$\mathrm{X}_{1 \mathrm{it}} \quad$ : Komite Audit

$\mathrm{X}_{2 \mathrm{it}} \quad$ : Managerial Ownership

$\begin{array}{ll}\mathrm{t} & \text { : Waktu } \\ \mathrm{i} & \text { : Perusahaan }\end{array}$

\section{Hasil Penelitian dan Pembahasan}

4.1 Analisis Statistik Deskriptif

Berikut adalah hasil statistik deskriptif setiap variabel operasional:

Tabel 2 Hasil Uji Statistik Deskriptif

\begin{tabular}{|c|c|c|c|c|c|}
\hline & $\begin{array}{c}\text { KA } \\
(\mathbf{X} 1)\end{array}$ & $\begin{array}{c}\text { MO } \\
(\mathbf{X} 2)\end{array}$ & $\boldsymbol{F O}(\mathbf{X 3})$ & $\mathbf{I D ( X 4 )}$ & $\boldsymbol{C O N A C C}(\mathbf{Y})$ \\
\hline Mean & 4,92 & 1,68 & 26,17 & 13,79 & $\begin{array}{r}\mathrm{Rp} \\
(1.205 .969 .807 .391)\end{array}$ \\
\hline Maksimum & 15,00 & 5,40 & 98,15 & 33,33 & $\begin{array}{c}\mathrm{Rp} \\
(1.677 .166 .942)\end{array}$ \\
\hline Minimum & 3,00 & 0,00 & 0,00 & 0,00 & $\begin{array}{c}\mathrm{Rp} \\
(2.767 .207 .000 .000)\end{array}$ \\
\hline St. Dev & 2,72 & 2,16 & 36,22 & 9,88 & $\begin{array}{c}\mathrm{Rp} \\
1.013 .106 .391 .410\end{array}$ \\
\hline
\end{tabular}

Sumber: Data telah diolah penulis (2018)

Berdasarkan tabel 2, rata-rata dari variabel komite audit (KA) pada periode 2012-2016 adalah 4,92 dengan nilai standar deviasi 2,72. Pada kondisi ini standar deviasi lebih rendah dari nilai rata-rata menunjukkan bahwa data komite audit berkelompok. Variabel managerial ownership $(M O)$ pada periode 2012-2016 memiliki nilai rata-rata sebesar 1,68 dengan standar deviasi sebesar 2,16. Pada kondisi nilai rata-rata lebih rendah daripada standar deviasi menunjukkan bahwa data kepemilikan manajerial tidak berkelompok. Variabel foreign ownership $(F O)$ pada periode 2012-2016 memiliki nilai rata-rata sebesar 26,17 dengan standar deviasi 36,22. Pada kondisi ini nilai rata-rata lebih besar dari standar deviasi. Hal ini menunjukkan bahwa data kepemilikan asing berkelompok. Variabel konservatisme akuntansi (CONACC) pada periode 20122016 memiliki nilai rata-rata sebesar -Rp 1.205.969.807.391 dengan standar deviasi Rp 1.013.106.391.410. Pada kondisi ini nilai rata-rata lebih rendah dari standar deviasi. Hal ini menunjukkan bahwa data konservatisme akuntansi tidak berkelompok. 


\subsection{Pemilihan Model Data Panel}

\subsubsection{Uji Signifikansi Fixed Effect (Uji Chow)}

Pengujian ini dilakukan untuk menentukan model common effect atau fixed effect yang akan digunakan dalam penelitian. Tabel 3 berikut ini menyajikan hasil Uji Chow menggunakan software Eviews 9.0.

\section{Tabel 3 Uji Signifikansi Fixed Effect (Uji Chow)}

\begin{tabular}{|c|c|c|c|}
\hline Effects Test & Statistic & d.f. & Prob. \\
\hline Cross-section F & 57.012330 & $(4,16)$ & 0.0000 \\
\hline Cross-section Chi-square & 68.119540 & 4 & 0.0000 \\
\hline
\end{tabular}

Sumber: output Eviews 9.0 (data diolah penulis, 2018)

Berdasarkan hasil uji chow, diperoleh nilai (cross section chi-square) dan (cross section $F$ ) masing-masing 0,0000 dan 0,0000 lebih kecil dari taraf signifikasi yaitu 0,05 . Sehingga keputusan $\mathrm{H}_{0}$ ditolak dan penelitian ini menggunakan fixed effect. Selanjutnya dilakukan pengujian untuk memilih metode antara fixed effect atau random effect.

\subsubsection{Uji Signifikansi Fixed Effect atau Random Effect (Uji Hausman)}

Pengujian ini dilakukan untuk menentukan apakah model fixed effect atau model random effect yang akan digunakan dalam penelitian. Tabel 4 berikut ini menyajikan hasil pengujian sebagai berikut:

Tabel 4 Uji Signifikansi Random Effect (Uji Hasuman)

Correlated Random Effects - Hausman Test

Equation: Untitled

Test cross-section random effects

\begin{tabular}{lrrr}
\hline \hline Test Summary & Chi-Sq. Statistic & Chi-Sq. d.f. & Prob. \\
\hline \hline Cross-section random & 228.049320 & 4 & 0.0000 \\
\hline \hline
\end{tabular}

Sumber: output Eviews 9.0 (data diolah penulis, 2018)

Berdasarkan hasil uji Hausman, diperoleh nilai cross-section random sebesar $0,0000<0,05$ dengan taraf signifikasi sebesar 5\% menyatakan bahwa Fixed Effect Model lebih baik dari pada Random Effect Model. Jadi, berdasarkan kedua uji tersebut dapat disimpulkan bahwa model regresi data panel yang sesuai untuk penelitian ini adalah Fixed Effect Model. 


\subsubsection{Uji Simultan (Uji F)}

Tabel 5 Hasil Pengujian Fixed Effect Specification (Simultan)

\begin{tabular}{lrlr}
\hline \hline R-squared & 0.962746 & Mean dependent var & $-1.21 \mathrm{E}+12$ \\
Adjusted R-squared & 0.944120 & S.D. dependent var & $1.01 \mathrm{E}+12$ \\
S.E. of regression & $2.39 \mathrm{E}+11$ & Akaike info criterion & 55.51513 \\
Sum squared resid & $9.18 \mathrm{E}+23$ & Schwarz criterion & 55.95393 \\
Log likelihood & -684.9392 & Hannan-Quinn criter. & 55.63684 \\
F-statistic & 51.68610 & Durbin-Watson stat & 1.335230 \\
Prob(F-statistic) & 0.000000 & & \\
\hline
\end{tabular}

Sumber: output Eviews 9.0 (data diolah penulis, 2018)

Dapat dilihat pada Tabel 5 bahwa besar signifikansi adalah 0,000000 atau dibawah 0,05 . Dengan besar signifikansi dibawah 0,05 maka dapat disimpulkan bahwa $\mathrm{H}_{\mathrm{a}}$ diterima, artinya komite audit $(\mathrm{KA})$, managerial ownership (MO), foreign ownership (FO), dan independent director (ID) berpengaruh signifikan secara simultan terhadap konservatisme akuntansi (CONACC). Berdasarkan tabel 5, dapat diketahui nilai adjusted $R$-Squared model penelitian adalah sebesar 0,944120 atau $94,4120 \%$. Dengan demikian, maka variabel independen yang terdiri komite audit, managerial ownership, foreign ownership, dan independent director dapat menjelaskan variabel dependen yaitu konservatisme akuntansi sebesar 94,4120\% sedangkan sisanya $5,588 \%$ dipengaruhi oleh variabel lain diluar penelitian.

\subsubsection{Uji Parsial (Uji t)}

Tabel 6 Hasil Pengujian Fixed Effect (Uji t)

\begin{tabular}{crrrr}
\hline \hline Variable & Coefficient & Std. Error & t-Statistic & Prob. \\
\hline \hline C & $-1.51 \mathrm{E}+12$ & $3.48 \mathrm{E}+11$ & -4.344255 & 0.0005 \\
KA & $9.52 \mathrm{E}+10$ & $2.64 \mathrm{E}+10$ & 3.606200 & 0.0024 \\
MO & $1.47 \mathrm{E}+13$ & $1.25 \mathrm{E}+13$ & 1.175090 & 0.2572 \\
FO & $1.22 \mathrm{E}+11$ & $2.93 \mathrm{E}+11$ & 0.416582 & 0.6825 \\
ID & $-3.19 \mathrm{E}+12$ & $1.25 \mathrm{E}+12$ & -2.547281 & 0.0215 \\
\hline \hline
\end{tabular}

Sumber: output Eviews 9.0 (data diolah penulis, 2018)

Berdasarkan Tabel 6, dapat diketahui nilai konstanta koefisien sehingga dapat dibentuk persamaan sebagai berikut:

$C O N A C C=-1.51 \mathrm{E}+12+9.52 \mathrm{E}+10 \mathrm{KA}+1.47 \mathrm{E}+13 \mathrm{MO}+1.22 \mathrm{E}+11 \mathrm{FO}-$

$$
\text { 3.19E+12ID +e }
$$

Berdasarkan hasil uji fixed effect method dapat disimpulkan bahwa:

a. Pada tabel 6 komite audit memiliki nilai prob. sebesar 0,0024 berada dibawah taraf signifikansi sebesar 0,05 atau $5 \%$ dan koefisien regresi bernilai positif sebesar $9.52 \mathrm{E}+10$. Dengan demikian, keputusan yang diambil adalah menerima $\mathrm{H}_{a}$ yang berarti komite audit dengan proksi audit meeting berpengaruh terhadap konservatisme akuntansi. Hasil penelitian menunjukkan bahwa komite audit memiliki koefisien regresi positif yang berarti komite audit dapat menurunkan konservatisme akuntansi.

b. Pada tabel 6 managerial ownership memiliki prob. sebesar 0,2527 berada diatas taraf signifikansi sebesar 0,05 atau $5 \%$ dan koefisien regresi bernilai positif sebesar $1.47 \mathrm{E}+13$. Dengan demikian, keputusan yang diambil adalah 
menerima $\mathrm{H}_{0}$ yang berarti managerial ownership tidak berpengaruh signifikan terhadap konservatisme akuntansi. Hasil penelitian menunjukkan bahwa kepemilikan manajerial memiliki koefisien regresi positif yang berarti kepemilikan manajerial dapat menurunkan konservatisme akuntansi

c. Pada tabel 6 foreign ownership memiliki prob. sebesar 0,6825 berada diatas taraf signifikansi sebesar 0,05 atau $5 \%$ dan koefisien regresi bernilai positif sebesar $1.22 \mathrm{E}+11$. Dengan demikian, keputusan yang diambil adalah menerima $\mathrm{H}_{0}$ yang berarti foreign ownership tidak berpengaruh signifikan terhadap konservatisme akuntansi. Hasil penelitian menunjukkan bahwa kepemilikan asing memiliki koefisien regresi positif yang berarti kepemilikan asing dapat menurunkan konservatisme akuntansi

d. Pada tabel 6 independent director memiliki prob. sebesar 0,0215 berada dibawah taraf signifikansi 0,05 atau $5 \%$ dan koefisien regresi bernilai negatif sebesar $-3.19 \mathrm{E}+12$. Dengan demikian, keputusan yang diambil adalah menerima $\mathrm{Ha}$ yang berarti independent director berpengaruh signifikan terhadap konservatisme akuntansi. Hasil penelitian menunjukkan direktur independen memiliki koefisien regresi negatif yang berarti direktur independen dapat menaikkan konservatisme akuntansi.

\section{Kesimpulan dan Saran}

\subsection{Kesimpulan}

Hasil analisis data yang dilakukan, diperoleh beberapa kesimpulan sebagai berikut:

1. Berdasarkan pengujian analisis deskriptif, dapat disimpulkan bahwa:

a. Variabel komite audit dengan proksi audit meeting memiliki nilai rata-rata sebesar 4,92 dengan standar deviasi sebesar 2,72. Nilai maksimum komite audit melakukan pertemuan (audit meeting) sebesar 15,00, sedangkan nilai minimum frekuensi audit meeting sebesar 3,00.

b. Variabel managerial ownership atau kepemilikan manajerial memiliki nilai rata-rata sebesar $1,68 \%$ dengan standar deviasi sebesar $2,16 \%$. Nilai maksimum kepemilikan manajerial $5,40 \%$, sedangkan nilai minimum kepemilikan manajerial sebesar $0 \%$.

c. Variabel foreign ownership atau kepemilikan asing memiliki nilai rata-rata sebesar $26,17 \%$ dengan standar deviasi sebesar $36,22 \%$. Nilai maksimum kepemilikan asing sebesar $98,15 \%$, sedangkan nilai minimum kepemilikan asing sebesar $0 \%$.

d. Variabel independent director atau direktur independen memiliki nilai ratarata sebesar $13,79 \%$ dengan standar deviasi sebesar 9,88\%. Nilai maksimum direktur independen sebesar $33,33 \%$, sedangkan nilai minimum persentase direktur independen sebesar $0 \%$.

e. Variabel konservatisme akuntansi memiliki nilai rata-rata sebesar 1.205.969.807.391 dengan standar deviasi sebesar 1.013.106.391.410. Nilai maksimum konservatisme akuntansi sebesar -1.677.166.942, sedangkan nilai minimum konservatisme akuntansi sebesar 2.767.207.000.000. 


\section{ISSN}

1. Secara simultan komite audit (audit meeting), managerial ownership, foreign ownership, dan independent director memiliki pengaruh yang signifikan terhadap konservatisme akuntansi pada perusahaan sektor industri ritel yang terdaftar di Bursa Efek Indonesia (BEI) tahun 2012-2016.

2. Pengaruh masing-masing secara parsial masing-masing variabel terhadap konservatisme akuntansi adalah sebagai berikut:

a. Komite Audit dengan proksi audit meeting berpengaruh signifikan dengan arah hubungan positif terhadap konservatisme akuntansi.

b. Managerial Ownership tidak berpengaruh signifikan terhadap konservatisme akuntansi.

c. Foreign Ownership tidak berpengaruh signifikan terhadap konservatisme akuntansi.

d. Independent Director berpengaruh signifikan dengan arah hubungan negatif terhadap konservatisme akuntansi.

a. Saran

Berdasarkan hasil penelitian yang telah dilakukan, penulis memberikan saran untuk pengembangan bagi penelitian selanjutnya adalah sebagai berikut:

1. Aspek Akademis

a. Meneliti pada perusahaan selain sektor industri ritel yang terdaftar di Bursa Efek Indonesia.

b. Disarankan untuk meneliti variabel lain yang diduga dapat berpengaruh terhadap konservatisme akuntansi seperti financial distress, kepemilikan institusional, debt covenant, pertumbuhan perusahaan, dan lain lain.

c. Menggunakan metode pengukuran lain untuk mengukur konservatisme seperti metode Zhang atau Basu.

2. Aspek Praktis

a. Bagi perusahaan, berdasarkan hasil penelitian diharapkan manajemen dapat meningkatkan kepemilikan manajerial pada perusahaan karena rata-rata persentase kepemilikan saham oleh pihak manajemen pada perusahaan sektor industri ritel masih tergolong rendah.

b. Bagi investor, berdasarkan hasil penelitian yang dilakukan penulis memberikan saran untuk investor agar melihat perusahaan yang memiliki proporsi kepemilikan asing yang tinggi. Karena, dengan kepemilikan asing yang tinggi perusahaan tidak konservatif dalam melaporkan laporan keuangan. 


\section{Daftar Pustaka:}

Bara, Bastian Dwi S. B. (2016). Pengaruh Kepemilikan Manajerial, Karakteristik Dewan, dan Debt Covenant terhadap Tingkat Konservatisme Akuntansi. Page: 38. Universitas Sebelas Maret Surakarta.

Basuki, Agus Tri., Prawoto, Nano. (2016). Analisis Regresi dalam Penelitian Ekonomi \& Bisnis (Dilengkapi Aplikasi SPSS \& Eviews). Jakarta: PT.RajaGrafindo Persada.

manta, Dea., dan Satwiko, Rutji. (2011). Faktor-faktor yang Mempengaruhi Kepemilikan Manajerial. Vo. 13, No.1. Page: 68. Jurnal Bisnis Akuntansi.

Kuspratiwi, Indhira., dan Widagdo, Ari Kuncara. (2014). Pengaruh IFRS dan Kepemilikan Asing terhadap Konservatisme Akuntansi. Page: 1871. Insitusional repository Satya Wacana Christian Universitty.

Oktomegah, Calvin. (2012). Faktor-faktor yang Mempengaruhi Penerapan Konservatisme pada Perusahaan Manufaktur di BEI. Vol. 1 No. 1. Page: 36. Jurnal IImiah Mahasiswa Akuntansi.

Pambudi, Januar Eky. (2017). Pengaruh Kepemilikan dan Debt Covenant terhadap Konservatisme Akuntansi. Vol. 1 No. 1. Page: 87. Jurnal Universitas Muhammadiyah Tangerang.

Peraturan Otoritas Jasa Keuangan Nomor. 55/POJK.04/2015. (2015). Pembentukan dan Pedoman Pelaksanaan Kerja Komite Audit. diunduh dari www.ojk.go.id diakses pada 14 Januari 2018.

Sarra, Hustna Darra. (2017). Pengaruh Konservatisme Akuntansi, Komite Audit dan Dewan Komisaris Independen terhadap Penghindaran Pajak . Vol. 1 No. 1. Page: 66. Jurnal Universitas Muhammadiyah Tangerang.

Savitri, Enni. (2016). Konservatisme Akuntansi; Cara Pengukuran, Tinjauan Empiris, dan Faktor-faktor yang Mempengaruhinya. Yogyakarta: Pustaka Sahila.

Sekaran, Uma. (2011). Metode Penelitian untuk Bisnis. Jakarta: Salemba Empat.

Sugiyono. (2014). Metode Penelitian Kuantitatif Kualitatif dan Kombinasi (Mix Method). Bandung: Alfabeta.

Surat Keputusan Direksi Bursa Efek Indonesia Nomor Kep-0001/BEl/01-2014. (2014). Pencatatan Saham dan Efek Bersifat Ekuitas Selain Saham Yang Diterbitkan Oleh Perusahaan Tercatat. diunduh dari www.martinaberto.co.id diakses pada 14 Januari 2018. 
ISSN

Jurnal Akuntansi Bisnis dan Ekonomi

2460-030X

Volume 4 No. 2, September 2018

Suwardjono. (2010). Teori Akuntansi Perekayasaan Pelaporan Keuangan (edisi ketiga). Yogyakarta: BFBE.

Widarjono, Agus. (2013). Elektrometrika Pengantar dan Aplikasinya (dilengkapi dengan Eviews). Yogyakarta: Ekonisia.

Wulandini, Dwinitia., dan Zulaikha (2012). Pengaruh Karakteristik Dewan Komisaris dan Komite Audit terhadap Tingkat Konservatisme Akuntansi.

Page: 1. Vol. 1 No. 2 Diponegoro Journal of Accounting.

https://finance.detik.com, diakses pada 1 Oktober 2017

https://finance.detik.com, diakses pada 14 Januari 2018 